Vol. 19(2010): 341-353.

\title{
Cultivar improvement and environmental variability in yield removed nitrogen of spring cereals and rapeseed in northern growing conditions according to a long-term dataset
}

\author{
Pirjo Peltonen-Sainio* and Lauri Jauhiainen \\ MTT Agrifood Research Finland, Plant Production Research, FI-31600 Jokioinen, Finland \\ *email pirjo.peltonen-sainio@mtt.fi
}

\begin{abstract}
The balance between applied and harvested nitrogen (yield removed nitrogen, YRN \%) is a recognized indicator of the risk of $\mathrm{N}$ leaching. In this study we monitored the genetic improvements and environmental variability as well as differences among crop species (spring cereals and rapeseed) in YRN in order to characterize changes that have occurred and environmental constraints associated with reducing $\mathrm{N}$ leaching into the environment. MTT long-term multi-location field experiments for spring cereals (Hordeum vulgare L., Avena sativa L. and Triticum aestivum L.), turnip rape (Brassica rapa L.), and oilseed rape (B. napus L.) were conducted in 1988-2008, covering each crop's main production regions. Yield $\left(\mathrm{kg} \mathrm{ha}^{-1}\right)$ was recorded and grain/seed nitrogen content $\left(\mathrm{N}_{\text {grain }}, \mathrm{g} \mathrm{kg}^{-1}\right)$ analyzed. Total yield $\mathrm{N}\left(\mathrm{N}_{\text {yield }}, \mathrm{kg} \mathrm{ha}^{-1}\right)$ was determined and YRN (\%) was calculated as a ratio between applied and harvested N. A mixed model was used to separate genetic and environmental effects. Year and location had marked effects on YRN and $\mathrm{N}_{\text {yield }}$. Average early and/or late season precipitation was often most advantageous for $\mathrm{N}_{\text {yield }}$ in cereals, while in dry seasons $\mathrm{N}$ uptake is likely restricted and in rainy seasons $\mathrm{N}$ leaching is often severe. Elevated temperatures during early and/or late growth phases had more consistent, negative impacts on YRN and/or $\mathrm{N}_{\text {yield }}$ for all crops, except oilseed rape. In addition to substantial variability caused by the environment, it was evident that genetic improvements in YRN have taken place. Hence, YRN can be improved by cultivar selection and through favouring crops with high YRN such as oat in crop rotations.
\end{abstract}

Key-words: nitrogen, growing conditions, cultivar, barley, oat, wheat, oilseed rape, turnip rape, yield, protein content 
Peltonen-Sainio and Jauhiainen. Yield removed nitrogen of spring cereals and rapeseed

\section{Introduction}

Risks associated with nitrogen leaching into natural water systems is high in northern Europe and especially in Finland with its more than 100000 lakes, $14000 \mathrm{~km}$ of Baltic coastline (Peltonen-Sainio et al. 2009d), and substantial annual precipitation averaging 500-650 mm for 1970-2000 (Finnish Meteorological Institute). While grasslands ensure continuous ground cover in the central and northern parts of Finland, spring-sown crops provide only partial ground cover in the main production areas in the south of the country. The capacity of spring sown crops to utilize nitrogen $(\mathrm{N})$ determines the potential risk for $\mathrm{N}$ leaching in the major production areas of Finland, with typical peaks in autumn and winter (Syväsalo et al. 2006). Nitrogen surplus is evident when the quantity of $\mathrm{N}$ applied is greater than that used for production of crop biomass (Rankinen et al. 2007). For this and economic reasons it is essential that $\mathrm{N}$ application occurs when the crop needs it, when it can be used for biomass production and is harvested instead of remaining unused in the soil (Peltonen-Sainio et al. 2009d). Yield removed nitrogen (YRN, \%) represents the ratio between applied and harvested $\mathrm{N}$.

Most $\mathrm{N}$ in harvested grains derives from $\mathrm{N}$ translocated from senescing vegetative plant parts (Cox et al. 1985, Papakosta and Gagianas 1991, Bulman and Smith 1994). When available, N can also be taken up from the soil during grain filling (Cox et al. 1985). In northern Europe this occurs, for example, when $\mathrm{N}$ is not taken up adequately at pre-heading because of typical early summer drought (Peltonen-Sainio et al. 2010), manure is used or elevated late summer temperatures stimulate excess $\mathrm{N}$ mobilization from soil (Rajala et al. 2007). Typically $N$ uptake values for fertilized wheat (Triticum aestivum L.) and barley (Hordeum vulgare L.) range from $20 \%$ to $100 \%$ of fertiliser applied in temperate regions (Gauer et al. 1992, Le Gouis et al. 2000, Sinebo et al. 2003, Noulas et al. 2004). This indicates considerable induced variability in $\mathrm{N}$ uptake according to growing conditions and challenges sustainable and economic fertilizer use.
Genetic variation in N uptake was reported for cereals (Kelly et al. 1995, Singh and Arora 2001). However, in wheat no consistent correlations between $\mathrm{N}$ uptake and year of cultivar release were recorded (Slafer et al. 1990, Calderini et al. 1995, Foulkes et al., 1998) in contrast to six-row barley (Bulman et al. 1993) and oat (Avena sativa L.) (Wych and Stuthman 1983, Welch and Leggett 1997). Modern cultivars have high yield potentials (Peltonen-Sainio et al. 2009b) associated with improvements in many N-related traits (Muurinen 2007). Early vigorous growth can also enhance $\mathrm{N}$ uptake as shown in modern wheat lines (Liao et al. 2004 and 2006). Genetic variation and gains were reported for other $\mathrm{N}$ traits that are important for efficient N use (Woodend et al. 1986, Papakosta 1994, Singh and Arora 2001). Improvements in key $\mathrm{N}$ traits are essential for efficient $\mathrm{N}$ uptake and use.

In this study, using 20-year multi-location trial datasets, we monitored the balance between genetic improvements and environmental variability for applied and harvested $\mathrm{N}$ in spring barley, oat and wheat as well as turnip rape (Brassica rapa $\mathrm{L}$.) and oilseed rape (B. napus L.) in order to characterize current position but also past changes in YRN. We also assessed environmental constraints associated with reducing $\mathrm{N}$ leaching into the environment for spring cereal and rapeseed production systems.

\section{Material and methods}

\section{Plant material, experimental design, measurements and estimations}

MTT long-term field experiments for spring cereals (barley, oat, and wheat), turnip rape, and oilseed rape were conducted in 1988-2008 at 12-19 different locations in Finland according to crop and production area. The experiments were part of the MTT Official Variety Trials and all followed procedures specified for that purpose (Kangas et al. 2005). In addition to MTT Agrifood Research 
Vol. 19(2010): 341-353.

Finland, which has numerous regional research units in Finland, some of the experiments were organized by plant breeding companies and private agricultural research stations.

All experiments were arranged as randomized complete block designs or incomplete block designs. Three to four replicates were used. Each year the tested set of cultivars and breeding lines changed, but long term-check cultivars were used. Annual turnover of cultivars and breeding lines was usually less than $20 \%$, which made it possible to separate effects of environment and genotype. Plots were 7-10 $\mathrm{m} \times 1.25 \mathrm{~m}$, depending on location and year. Seeding rate depended on crop, conforming to the commonly used seeding rates in Finland. Weeds were chemically controlled with commonly used agents. Diseases were not routinely controlled with fungicides to allow differences among entries in disease resistance to be recorded. Fertilizer use depended on cropping history, soil type and fertility and was comparable with standard practices in Finland. There was, however, no systematic reduction or increase in $\mathrm{N}$ fertilizer use during the 20 -year study period.

Cereals and rapeseed were combine-harvested and the grain/seed weighed $\left(\mathrm{kg} \mathrm{ha}^{-1}\right)$ after removing straw, weed seeds, and other particles. Grain/ seed moisture content was determined by weighing samples before and after oven drying, or more recently by using a GAC II grain analysis computer (DICKEY-john corporation, USA). Grain and seed nitrogen content $\left(\mathrm{N}_{\text {grain }}, \mathrm{g} \mathrm{kg}^{-1}\right)$ were analyzed using the Kjeldahl-method. Yield and $\mathrm{N}$ content were both adjusted to $0 \%$ moisture content. Total yield $\mathrm{N}\left(\mathrm{N}_{\text {yield }}, \mathrm{kg} \mathrm{ha}^{-1}\right)$ was calculated by multiplying yield $\left(\mathrm{kg} \mathrm{ha}^{-1}\right)$ by $\mathrm{N}_{\text {grain }}(\%)$ and dividing by one hundred.

Yield removed N (YRN, \%) was calculated by dividing $\mathrm{N}_{\text {yield }}\left(\mathrm{kg} \mathrm{ha}^{-1}\right)$ by applied $\mathrm{N}$ fertilizer rate $\left(\mathrm{kg} \mathrm{ha}^{-1}\right)$ and multiplying by one hundred. As no unfertilised plots were included in these longterm experiments, contribution of soil derived $\mathrm{N}$ to YRN could not be distinguished. In addition to YRN, we approximated the likely minimum to maximum range of $\mathrm{N}$ use efficiency $\left(\mathrm{NUE}_{\text {range }}, \mathrm{kg}\right.$ $\mathrm{kg} \mathrm{N}^{-1}$ ) and $\mathrm{N}$ harvest index $\left(\mathrm{NHI}_{\text {range }}, \%\right)$. Due to absence of actual measurements of harvest index
(HI) for these long-term datasets, for above-ground vegetative biomass (VEGE, $\mathrm{kg} \mathrm{ha}^{-1}$ ) we estimated ranges of $\mathrm{HI}$ documented for Finnish conditions (Peltonen-Sainio et al. 2008, Hakala et al. 2009, Pahkala et al. 2009). These were $0.44-0.60$ for tworow barley, $0.47-0.63$ for six-row barley, $0.40-0.56$ for oat, $0.35-0.48$ for wheat, and $0.28-0.38$ for turnip rape and oilseed rape. Furthermore, due to lack of information on $\mathrm{N}$ content of vegetative aboveground biomass $\left(\mathrm{N}_{\text {vege }}, \mathrm{g} \mathrm{kg}^{-1}\right)$ in these experiments, we used mean estimates of $0.58 \%, 0.43 \%, 0.41 \%$, $0.42 \%, 0.90 \%$ and $0.90 \%$ for two- and six-row barley, oat, wheat, turnip rape and rapeseed, respectively. These estimates were based on results from e.g. Muurinen et al. (2007), Peltonen-Sainio et al. (2009c and unpublished crude data), and Hocking et al. (1997). By this means, NUE was estimated as yield divided by $\left(\mathrm{N}_{\text {grain }}+\mathrm{N}_{\text {vege }}\right)$, having minimum and maximum estimates for $\mathrm{N}_{\text {vege }}$ according to HI range typical for each crop. Similarly, $\mathrm{NHI}_{\text {range }}$ was estimated as $\mathrm{N}_{\text {grain }}$ divided by $\left(\mathrm{N}_{\text {grain }}+\mathrm{N}_{\text {vege }}\right)$ and multiplied by one hundred. As $\mathrm{NUE}_{\text {range }}$ and $\mathrm{NHI}_{\text {range }}$ were only rough estimates, they were not necessarily included in statistical analyses. Benchmarking with documented cereal NHI values, showed our $\mathrm{NHI}_{\text {range }}$ estimates to be close to or even exceeding $80 \%$ (Spiertz and de Vos 1983, Feil 1997, Noulas et al. 2004), though $\mathrm{NHI}$ is strongly affected by e.g. weather conditions (Feil, 1997).

\section{Statistical analyses}

The main purpose of the statistical analysis of yield and nitrogen content was to estimate two effects: genetic and environmental effects. A mixed model technique was applied for this purpose using the following statistical model for each individual crop:

$$
y_{i j k}=\mu+\alpha_{i}+\beta_{j k}+\varepsilon_{i j k}
$$

where $y_{i j}$ is the observed seed yield or nitrogen content of the $\mathrm{i}^{\text {th }}$ cultivar in the $\mathrm{j}^{\text {th }}$ location and $\mathrm{k}^{\text {th }}$ year, 
Peltonen-Sainio and Jauhiainen. Yield removed nitrogen of spring cereals and rapeseed

$\mu$ is the intercept, $\alpha_{i}$ is the effect of the $i^{\text {th }}$ cultivar, $\beta_{\mathrm{jk}}$ is the effect of the $\mathrm{jk}^{\mathrm{th}}$ experiment and $\varepsilon_{\mathrm{ijk}}$ is the normally distributed residual error.

Nitrogen traits of cultivars were compared using the estimated cultivar effects, $\hat{\alpha}_{i}$. Cultivars included in 20 or more experiments contributed to the comparison. For oilseed rape, limitation was decreased to 10 experiments because the annual number of trials was smaller than for other crops. By this means, 60 two-row barley, 51 six-row barley, 65 oat, 44 wheat, 33 turnip rape and 22 oilseed rape cultivars were compared.

During the next stage the estimated environmental effects, $\hat{\beta}$, were examined graphically by drawing box-plots for all experimental sites and years. Correlation analysis was performed to measure relationships between studied traits and variables. Correlation analysis was applied using the estimated environmental effects.

Subsequently $\hat{\beta}$ values were used to compare different crops using the following mixed model and the REML (Restricted Maximum Likelihood) estimation method:

$\underset{j k l}{\hat{\beta}}=\mu+\phi_{l}+\gamma_{j}+\eta_{k}+1_{j k}+\varphi_{j l}+\kappa_{k l}+\varepsilon_{j k l}$

where $\hat{\beta}$ is the previously estimated environmental effect or derivative of these estimates $\left(\mathrm{N}_{\text {yield }}\right.$, $\mathrm{N}$ rate, YRN, NUE estimate, NHI estimate) for the $1^{\text {th }}$ crop, $\mu$ is the intercept, $\phi_{1}$ is the effect of the $1^{\text {th }}$ crop while $\gamma_{\mathrm{j}}, \eta_{\mathrm{k}}, \mathrm{l}_{\mathrm{jk}}, \varphi_{\mathrm{jl}}, \kappa_{\mathrm{kl}}$, and $\varepsilon_{\mathrm{jk} l}$ are random effects of location, year, location $\mathrm{x}$ year, crop $\mathrm{x}$ location, crop x year, and residual, respectively. The model assumes that all the random effects are mutually independent. This model can estimate the mutually comparable crop means despite not testing the complete set of crops every year at all the locations.

The precipitation during early (15 May to 31 June) and late growing seasons (1 July to 15 Aug.) was calculated for each experiment from the data of the Finnish Meteorological Institute. According to precipitation, experiments were classified into three categories: dry, average or rainy. Early seasons with precipitation $\leq 55 \mathrm{~mm}, 56-104 \mathrm{~mm}$ and $\geq 105 \mathrm{~mm}$ were considered to be dry, average and rainy ( $\pm 5 \mathrm{~mm}$ depending on crop species), while in late season $\leq 82 \mathrm{~mm}, 83-144 \mathrm{~mm}$ and $\geq 145 \mathrm{~mm}$, respectively ( $\pm 10 \mathrm{~mm}$ depending on crop species). The average condition contained $50 \%$ of experiments, while dry and rainy only $25 \%$. This classification was done for both seasons and relationships between precipitation, YRN, and $\mathrm{N}_{\text {yield }}$ were examined using following model:

$$
y_{i j k}=\mu+\omega_{i}+v_{j}+\tau_{i j}+\varepsilon_{i j k}
$$

where $\mathrm{y}_{\mathrm{ijk}}$ is the observed $\mathrm{YRN}$ or $\mathrm{N}_{\text {yield }}, \mu$ is the intercept, $\omega_{i}$ is the effect of precipitation in the early season ( $i=d r y$, average, or rainy), $v_{j}$ is the effect of precipitation late in the season $(\mathrm{j}=\mathrm{dry}$, average, or rainy), $\tau_{\mathrm{ij}}$ is the interaction between two seasons, and $\varepsilon_{\mathrm{ijk}}$ is the residual error. The relationships between mean temperature and $\mathrm{YRN}$ and $\mathrm{N}_{\text {yield }}$ were examined using the same procedure. All the statistical analyses were done using SAS/MIXED and SAS/CORR software (SAS 1999).

\section{Results}

Crop species differed significantly in yield, $\mathrm{N}_{\text {grain }}$, $\mathrm{N}_{\text {yield }}$, and YRN as well as in $\mathrm{N}$ fertilizer used (Table 1). Oat had superior yield, $\mathrm{N}_{\text {yield }}$ and YRN despite receiving less $\mathrm{N}$ fertilizer than two- and six-row barley. Turnip rape and oilseed rape contrasted with oat. Their YRN was only close to half of that in oat, although the $\mathrm{N}$ content in seeds clearly exceeded that of cereals. Of the cereals wheat had the lowest YRN. All crop yields were strongly and positively associated with $\mathrm{N}_{\text {yield }}$ and YRN, but were negatively associated with grain or seed $\mathrm{N}$ content (Table 2). Depending on crop, a $100 \mathrm{~kg} \mathrm{ha}^{-1}$ increase in yield resulted in 1.5-2.7 percentage unit increase in YRN and $1.5-3.0 \mathrm{~kg} \mathrm{ha}^{-1}$ increase in $\mathrm{N}_{\text {yield }}$. In contrast, YRN was positively and significantly associated with $\mathrm{N}_{\text {grain }}(p<0.001, \mathrm{r}=0.25)$ only for oat. Approximating the range for NUE and NHI suggested that cereals clearly out-perform turnip rape and 
Vol. 19(2010): 341-353.

oilseed rape: even the estimated maxima for NUE and NHI of oil crops were lower than estimated minima for NUE and NHI for any of the spring cereals (Table 1).

In general, location $\mathrm{x}$ year was the dominant source of variation associated with yield, $\mathrm{N}_{\text {grain }}$, $\mathrm{N}_{\text {yield }}$, and YRN (Table 3). Depending on the year, the yield ranged from -799 to $533 \mathrm{~kg} \mathrm{ha}^{-1}$ compared with the mean yield over all years. Similarly $\mathrm{N}_{\text {grain }}$ ranged from -0.3 to $0.3 \%$ units, $\mathrm{N}_{\text {yield }}$ from -7.8 to $7.2 \mathrm{~kg} \mathrm{ha}^{-1}$, and YRN from -9 to $11 \%$ units. Variation due to location exceeded that for year only for YRN, where it was -15 to $25 \%$ units. High within year and inter-annual variation for $\mathrm{N}_{\text {yield }}$ and YRN (Fig. 1 and 2) emphasized comprehensive instability in both $\mathrm{N}$ traits and in all crops. The slight differences in favour of wheat and rapeseed, which seemed to be more stable than the other cereals, is probably an artefact resulting from later maturing species grown in more southerly regions than oat and six- and two-row barley. Although total range of variability between the lowest and highest recorded $\mathrm{N}_{\text {yield }}$ and YRN did not show any clear and consistent trend of reduced within year variability, for oat and two- and six-row barley, the recorded values were more concentrated around their mean and/or median in the latter than the former part of the 20 year study period, especially regarding $\mathrm{N}_{\text {yield }}$. There was no consistent tendency for improved mean $\mathrm{N}_{\text {yield }}$ and YRN over time. On the other hand, despite marked variability in $\mathrm{N}$ traits of cereals, years with exceptionally low YRN and $\mathrm{N}_{\text {yield }}$ were rare. Such years were 1998 and 1999 for

Table 1. Comparable crop means (standard errors of means in parentheses) for grain or seed yield, grain or seed $\mathrm{N}$ content $\left(\mathrm{N}_{\text {grain }}\right)$, $\mathrm{N}$ yield, $\mathrm{N}$ fertilizer application rate, yield removed $\mathrm{N}$ (YRN), and estimated ranges of $\mathrm{N}$ use efficiency (NUE) and $\mathrm{N}$ harvest index (NHI).

\begin{tabular}{|c|c|c|c|c|c|c|c|c|c|}
\hline \multirow[t]{2}{*}{ Crop } & \multirow[t]{2}{*}{$\begin{array}{c}\text { Yield } \\
\left(\mathrm{kg} \mathrm{ha}^{-1}\right)\end{array}$} & \multirow[t]{2}{*}{$\begin{array}{l}\mathrm{N}_{\text {grain }} \\
(\%)\end{array}$} & \multirow[t]{2}{*}{$\begin{array}{c}\mathrm{N}_{\text {yield }} \\
\left(\mathrm{kg} \mathrm{ha}^{-1}\right)\end{array}$} & \multirow[t]{2}{*}{$\begin{array}{c}\mathrm{N} \text { rate } \\
\left(\mathrm{kg} \mathrm{ha}^{-1}\right)\end{array}$} & \multirow[t]{2}{*}{$\begin{array}{l}\text { YRN } \\
(\%)\end{array}$} & \multicolumn{2}{|c|}{$\begin{array}{l}\text { NUE estimate } \\
\left(\mathrm{kg} \mathrm{kg}^{-1} \mathrm{~N}\right)\end{array}$} & \multicolumn{2}{|c|}{$\begin{array}{c}\text { NHI estimate } \\
(\%)\end{array}$} \\
\hline & & & & & & Min & $\operatorname{Max}$ & Min & Max \\
\hline Two-row barley & $4990(128)$ & $1.9(0.05)$ & $81(2.4)$ & $89(2.7)$ & $95(4.6)$ & 42 & 50 & 69 & 81 \\
\hline Six-row barley & $4740(125)$ & $2.0(0.05)$ & $80(2.4)$ & $89(2.7)$ & $93(4.5)$ & 46 & 52 & 78 & 87 \\
\hline Oat & $5270(127)$ & $2.1(0.05)$ & $93(2.4)$ & $88(2.7)$ & $110(4.5)$ & 42 & 49 & 74 & 84 \\
\hline Wheat & 4450 (139) & $2.2(0.05)$ & $82(2.6)$ & $102(2.9)$ & $83(5.0)$ & 38 & 44 & 70 & 80 \\
\hline Turnip rape & 1940 (138) & $3.6(0.05)$ & $58(2.6)$ & $101(2.9)$ & $58(4.9)$ & 19 & 22 & 57 & 67 \\
\hline Oilseed rape & $2020(156)$ & $3.7(0.05)$ & $63(3.0)$ & $105(3.2)$ & $61(5.5)$ & 19 & 22 & 58 & 68 \\
\hline$p$-value & $<0.001$ & $<0.001$ & $<0.001$ & $<0.001$ & $<0.001$ & $<0.001$ & $<0.001$ & $<0.001$ & $<0.001$ \\
\hline
\end{tabular}

Table 2. Correlations of grain or seed yield $\left(\mathrm{kg} \mathrm{ha}^{-1}\right)$ with grain $\mathrm{N}$ content $\left(\mathrm{N}_{\text {grain }}, \%\right), \mathrm{N}$ yield $\left(\mathrm{kg} \mathrm{ha}^{-1}\right)$ and yield removed $\mathrm{N}$ (YRN, \%), and the effect of increase in yield by $100 \mathrm{~kg} \mathrm{ha}^{-1}$ on $\mathrm{N}$ traits for spring cereals and rapeseed according to 20 years multi-location Official Variety Trials (1988-2008).

\begin{tabular}{|c|c|c|c|c|c|c|c|c|c|}
\hline \multirow[t]{2}{*}{ Crop } & \multicolumn{3}{|c|}{ Yield and $\mathrm{N}_{\text {grain }}$} & \multicolumn{3}{|c|}{ Yield and $\mathrm{N}_{\text {yield }}$} & \multicolumn{3}{|c|}{ Yield and YRN } \\
\hline & $\begin{array}{l}\text { Correlation } \\
\text { coefficient }\end{array}$ & $p$-value & $\begin{array}{l}\text { Change } \\
\text { (\% units) }\end{array}$ & $\begin{array}{l}\text { Correlation } \\
\text { coefficient }\end{array}$ & $p$-value & $\begin{array}{l}\text { Change } \\
\left(\mathrm{kg} \mathrm{ha}^{-1}\right)\end{array}$ & $\begin{array}{l}\text { Correlation } \\
\text { coefficient }\end{array}$ & $p$-value & $\begin{array}{l}\text { Change } \\
\text { (\% units) }\end{array}$ \\
\hline Two-row barley & -0.26 & $<0.001$ & -0.005 & 0.90 & $<0.001$ & 1.5 & 0.70 & $<0.001$ & 1.9 \\
\hline Six-row barley & -0.25 & $<0.001$ & -0.005 & 0.89 & $<0.001$ & 1.6 & 0.71 & $<0.001$ & 2.0 \\
\hline Oat & -0.14 & 0.02 & -0.003 & 0.86 & $<0.001$ & 1.7 & 0.63 & $<0.001$ & 2.3 \\
\hline Wheat & -0.35 & $<0.001$ & -0.009 & 0.87 & $<0.001$ & 1.6 & 0.59 & $<0.001$ & 1.5 \\
\hline Turnip rape & -0.17 & 0.03 & -0.011 & 0.95 & $<0.001$ & 2.9 & 0.80 & $<0.001$ & 2.7 \\
\hline Rapeseed & -0.33 & $<0.01$ & -0.020 & 0.96 & $<0.001$ & 3.0 & 0.79 & $<0.001$ & 2.5 \\
\hline
\end{tabular}


Peltonen-Sainio and Jauhiainen. Yield removed nitrogen of spring cereals and rapeseed

all cereals and for cereals other than wheat 1988 also. In contrast, such failures were more frequent for turnip rape and oilseed rape (Fig. 1 and 2).

Many significant effects were associated with growing conditions through responses of YRN and $\mathrm{N}_{\text {yield }}$ to precipitation and temperature. Precipitation effects at early and/or late season were frequently recorded for $\mathrm{N}_{\text {yield }}$, though not in two-row barley and turnip rape (Table 4). In the case of significant effects, the trend was that rainy early or late seasons resulted in lower $\mathrm{N}_{\text {yield }}$ compared with below average precipitation conditions, while there were

Table 3. Sources of variation for grain or seed yield, grain or seed $\mathrm{N}$ content $\left(\mathrm{N}_{\text {grain }}\right), \mathrm{N}$ yield, $\mathrm{N}$ fertilizer application rate, and yield removed $\mathrm{N}$ (YRN).

\begin{tabular}{|c|c|c|c|}
\hline Trait and source of variation & Variance & Ratio $^{\mathrm{a}}$ & $\begin{array}{l}\text { Range of variation compared to mean } \\
\text { caused by year and location ( } p \text {-value) }\end{array}$ \\
\hline \multicolumn{4}{|l|}{ Yield $\left(\mathrm{kg} \mathrm{ha}^{-1}\right)$ : } \\
\hline Year & 141579 & 0.19 & $-799(<0.001)-533(<0.01)$ \\
\hline Location & 32474 & 0.04 & - \\
\hline Location $\times$ year & 303299 & 0.40 & \\
\hline Year $\times$ crop & 25076 & 0.03 & \\
\hline Location $\times$ crop & 33829 & 0.04 & \\
\hline Residual & 760948 & 1.00 & \\
\hline \multicolumn{4}{|l|}{$\mathrm{N}_{\text {grain }}(\%)$ : } \\
\hline Year & 0.021 & 0.72 & $-0.3(<0.001)-0.3(<0.001)$ \\
\hline Location & 0.012 & 0.39 & $-0.2(0.01)-0.2(0.03)$ \\
\hline Location $\times$ year & 0.023 & 0.78 & \\
\hline Year $\times$ crop & 0.004 & 0.14 & \\
\hline Location $\times$ crop & 0.002 & 0.05 & \\
\hline Residual & 0.030 & 1.00 & \\
\hline \multicolumn{4}{|l|}{$\mathrm{N}_{\text {yield }}\left(\mathrm{kg} \mathrm{ha}^{-1}\right)$ : } \\
\hline Year & 26.9 & 0.10 & $-7.8(0.01)-7.2(0.03)$ \\
\hline Location & 29.5 & 0.11 & $0.0-7.0(0.05)$ \\
\hline Location $\times$ year & 133.6 & 0.50 & \\
\hline Year $\times$ crop & 7.8 & 0.03 & \\
\hline Location $\times$ crop & 14.5 & 0.05 & \\
\hline Residual & 265.4 & 1.00 & \\
\hline \multicolumn{4}{|l|}{$\mathrm{N}$ rate $\left(\mathrm{kg} \mathrm{ha}^{-1}\right)$ : } \\
\hline Year & 0.0 & 0.00 & - \\
\hline Location & 85.9 & 0.50 & $-16.9(<0.001)-18.9(<0.001)$ \\
\hline Location $\times$ year & 25.4 & 0.15 & \\
\hline Year $\times$ crop & 0.0 & 0.00 & \\
\hline Location $\times$ crop & 38.5 & 0.22 & \\
\hline Residual & 172.6 & 1.00 & \\
\hline \multicolumn{4}{|l|}{ YRN (\%): } \\
\hline Year & 0.4 & 0.06 & $-9(0.03)-11(<0.01)$ \\
\hline Location & 1.8 & 0.26 & $-15(0.08)-25(<0.001)$ \\
\hline Location $\times$ year & 1.9 & 0.28 & \\
\hline Year $\times$ crop & 0.0 & 0.00 & \\
\hline Location $\times$ crop & 1.0 & 0.14 & \\
\hline Residual & 7.0 & 1.00 & \\
\hline
\end{tabular}


Vol. 19(2010): 341-353.
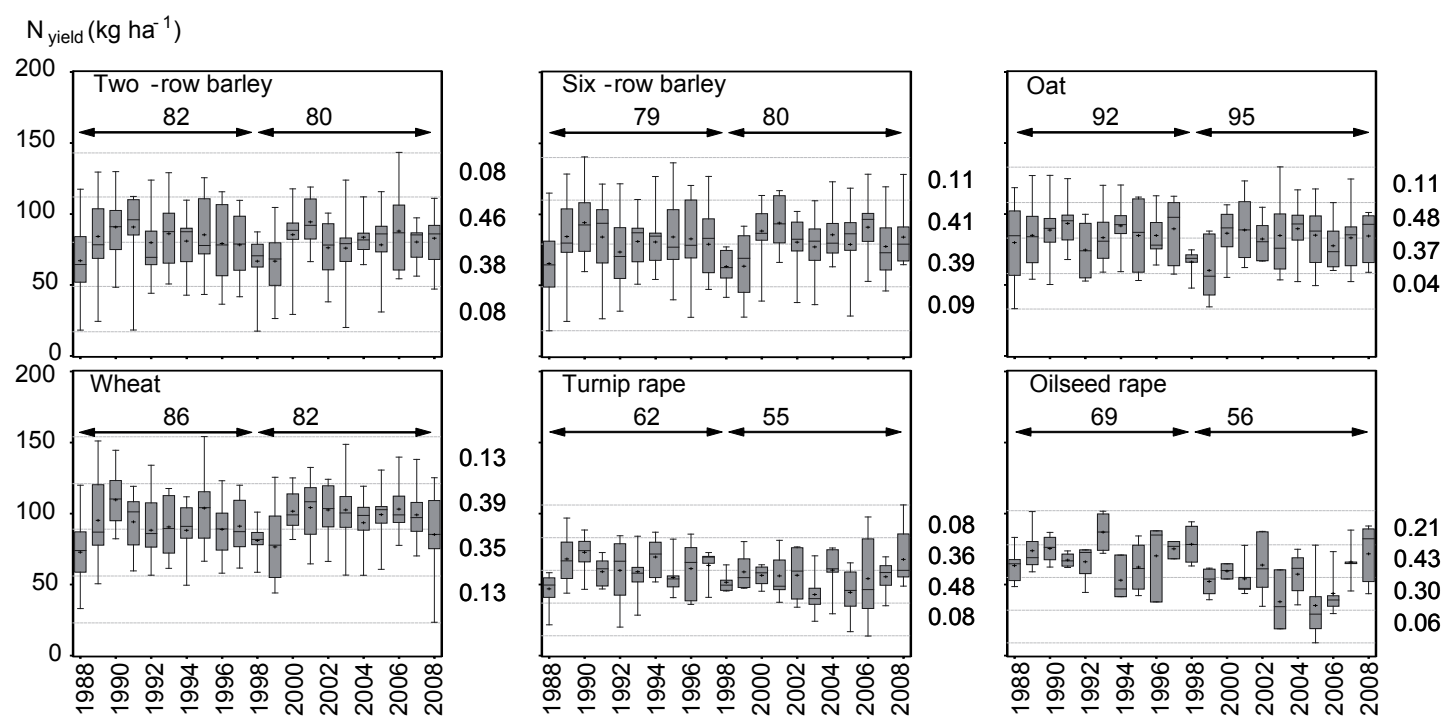

Fig. 1. Within year and between years variation in mean (asterisk), median (line within each box), standard deviation (the lowest and highest limit of the box), minimum, and maximum (bottom and top segment of the line, respectively) for $\mathrm{N}$ yield $\left(\mathrm{kg} \mathrm{ha}^{-1}\right)$ of spring cereals and rapeseed. Also frequencies (in right-hand side) for each of the four groups having regular intervals between minimum and maximum $\mathrm{N}$ yield (shown with dash lines) are indicated as well as mean N yields above an arrow for early (1988-1998) and late study years (1999-2008). Mean N fertilizer application rates were $89 \mathrm{~kg} \mathrm{ha}^{-1}$ for two- and six-row barley, $88 \mathrm{~kg} \mathrm{ha}^{-1}$ for oat, $102 \mathrm{~kg} \mathrm{ha}^{-1}$ for wheat, $101 \mathrm{~kg} \mathrm{ha}^{-1}$ for turnip rape, and $105 \mathrm{~kg} \mathrm{ha}^{-1}$ for oilseed rape.
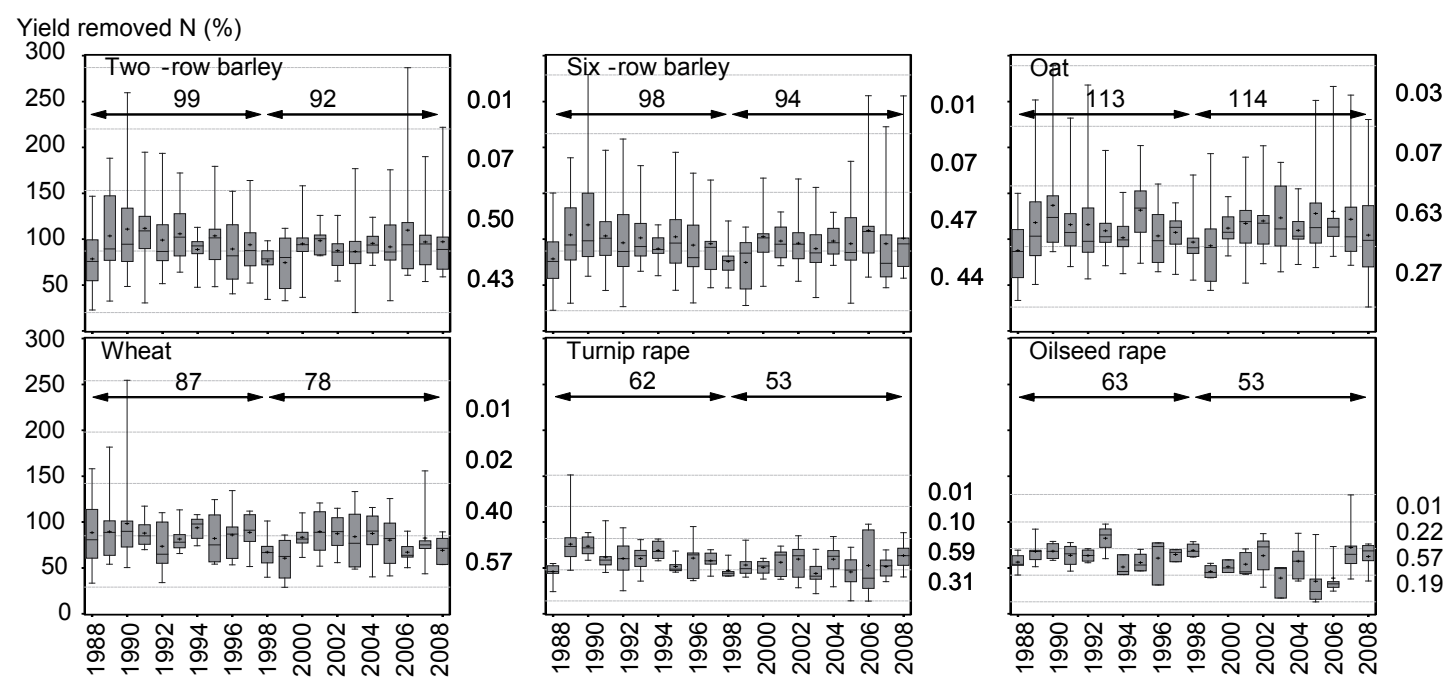

Fig. 2. Within year and between years variation in mean (asterisk), median (line within each box), standard deviation (the lowest and highest limit of the box), minimum, and maximum (bottom and top segment of the line, respectively) for yield removed N (YRN, \%) of spring cereals and rapeseed. Also frequencies (in right-hand side) for each of the four groups having regular intervals between minimum and maximum YRN (shown with dash lines) are indicated as well as mean YRN above an arrow for early (1988-1998) and late study years (1999-2008). Mean N fertilizer application rates were $89 \mathrm{~kg} \mathrm{ha}^{-1}$ for two- and six-row barley, $88 \mathrm{~kg} \mathrm{ha}^{-1}$ for oat, $102 \mathrm{~kg} \mathrm{ha}^{-1}$ for wheat, $101 \mathrm{~kg} \mathrm{ha}^{-1}$ for turnip rape, and $105 \mathrm{~kg} \mathrm{ha}^{-1}$ - for oilseed rape. 
Peltonen-Sainio and Jauhiainen. Yield removed nitrogen of spring cereals and rapeseed

no consistent differences in effect between dry and average precipitation conditions for $\mathrm{N}_{\text {yield }}$. For YRN late season precipitation was close to significant, but only for six-row barley and oilseed rape (Table 4). For six-row barley, high precipitation markedly reduced YRN compared with average conditions while for oilseed rape dry conditions resulted in low YRN. No significant interactions between early or late season precipitation were re- corded for any of the crops or for YRN or $\mathrm{N}_{\text {yield }}$. Temperature had very consistent and significant or close to significant effect on YRN of two-row barley (at late season), six-row barley (early and late), oat (late), and turnip rape (early). YRN was increased at low to average temperatures and at average to high temperatures (Table 5). Temperature effects on $\mathrm{N}_{\text {yield }}$ were, however, dependent on crop and time of season. Above average temperatures

Table 4. Significant precipitation effects at early and late growing season on N yield and yield removed N (YRN) of spring cereals and rapeseed. Seasons are grouped to be average, dry, or rainy and mean estimates of $\mathrm{N}$ trait for each condition are shown with standard errors of the means in parentheses.

\begin{tabular}{|c|c|c|c|c|c|}
\hline \multirow[t]{2}{*}{ Trait and crop } & \multicolumn{2}{|l|}{ Significance } & \multicolumn{3}{|c|}{ Mean estimate (s.e.) for $\mathrm{N}$ trait and condition } \\
\hline & Early or late season & $p$-value & Dry & Average & Rainy \\
\hline \multicolumn{6}{|l|}{ YRN (\%): } \\
\hline Six-row barley & Late & 0.09 & $90(4.8)$ & $99(2.9)$ & $88(4.8)$ \\
\hline Oilseed rape & Late & 0.06 & $49(4.7)$ & $63(3.4)$ & $63(5.3)$ \\
\hline \multicolumn{6}{|l|}{$\mathrm{N}_{\text {yield }}\left(\mathrm{kg} \mathrm{ha}^{-1}\right)$ : } \\
\hline Six-row barley & Early & 0.01 & $75(3.0)$ & $83(1.9)$ & $73(3.2)$ \\
\hline Six-row barley & Late & 0.04 & $77(3.1)$ & $82(1.8)$ & $73(3.1)$ \\
\hline Oat & Early & $<0.01$ & $88(3.1)$ & $97(2.0)$ & $87(2.9)$ \\
\hline Oat & Late & 0.03 & $94(2.9)$ & $94(2.0)$ & $84(3.1)$ \\
\hline Wheat & Early & 0.03 & $73(4.4)$ & $86(2.5)$ & $85(4.0)$ \\
\hline Oilseed rape & Late & 0.09 & $66(6.1)$ & $61(3.3)$ & $60(5.2)$ \\
\hline
\end{tabular}

Table 5. Significant temperature effects at early and late growing season on N yield and yield removed N (YRN) of spring cereals and rapeseed. Seasons are grouped to have average, low, or high temperatures and mean estimates of $\mathrm{N}$ trait for each condition are shown with standard errors of means in parentheses.

\begin{tabular}{|c|c|c|c|c|c|}
\hline \multirow[t]{2}{*}{ Trait and crop } & \multicolumn{2}{|l|}{ Significance } & \multicolumn{3}{|c|}{ Mean estimate (s.e.) for $\mathrm{N}$ trait and temperature condition } \\
\hline & Early or late season & $p$-value & Low & Average & High \\
\hline \multicolumn{6}{|l|}{ YRN (\%): } \\
\hline Two-row barley & Late & 0.06 & $100(4.4)$ & $95(3.1)$ & $85(4.6)$ \\
\hline Six-row barley & Early & 0.11 & $99(4.3)$ & $96(3.0)$ & $87(4.1)$ \\
\hline Six-row barley & Late & 0.03 & $100(4.0)$ & $97(2.9)$ & $85(4.5)$ \\
\hline Oat & Late & 0.11 & $118(5.1)$ & $111(3.6)$ & $102(5.5)$ \\
\hline Turnip rape & Early & 0.03 & $65(3.4)$ & $57(2.3)$ & $52(3.4)$ \\
\hline \multicolumn{6}{|l|}{$\mathrm{N}_{\text {yield }}\left(\mathrm{kg} \mathrm{ha}^{-1}\right)$ : } \\
\hline Two-row barley & Early & 0.05 & $82(3.0)$ & $82(2.3)$ & $74(2.8)$ \\
\hline Six-row barley & Early & $<0.01$ & $81(2.8)$ & $83(1.9)$ & $71(2.6)$ \\
\hline Oat & Early & $<0.01$ & $91(2.9)$ & $96(2.0)$ & $84(2.9)$ \\
\hline Wheat & Early & $<0.001$ & $94(3.8)$ & $81(2.5)$ & $73(4.3)$ \\
\hline Turnip rape & Early & 0.05 & $64(3.1)$ & $57(2.1)$ & $53(3.1)$ \\
\hline Turnip rape & Late & 0.07 & $54(3.1)$ & $62(2.1)$ & $57(3.1)$ \\
\hline
\end{tabular}


Vol. 19(2010): 341-353.

early during the season reduced $\mathrm{N}_{\text {yield }}$ of all cereal species and turnip rape. For turnip rape, average temperatures during late season were most advantageous for $\mathrm{N}_{\text {yield }}$.

Comprehensive differences among cultivars were recorded for YRN and $\mathrm{N}_{\text {yield }}$ (Table 6). We found the highest relative derived differences among cultivars for $\mathrm{N}$ traits in oilseed rape, for which the ranges between the weakest and strongest cultivars were $31 \%$ units for YRN and $33 \mathrm{~kg}$ ha $^{-1}$ for $\mathrm{N}_{\text {yield }}$. In contrast to oilseed rape, differences among turnip rape cultivars were more modest: $14 \%$ units for YRN and $14 \mathrm{~kg} \mathrm{ha}^{-1}$ for $\mathrm{N}_{\text {yield }}$. For cereals the range was greatest for oats, reaching $35 \%$ units for YRN and $29 \mathrm{~kg} \mathrm{ha}^{-1}$ for $\mathrm{N}_{\text {yield }}$. For wheat it was $24 \%$ units and $24 \mathrm{~kg} \mathrm{ha}^{-1}$, for two-row barley $21 \%$ units and $19 \mathrm{~kg} \mathrm{ha}^{-1}$, and for six-row barley $26 \%$ units and $20 \mathrm{~kg} \mathrm{ha}^{-1}$. When comparing year of release for the top five and bottom five cultivars, according to their YRN, it was evident that in general, and for all crops, modern cultivars outperformed the older ones (Table 7). This was particularly striking in six-row barley, wheat, turnip

Table 6. Cultivar differences for $\mathrm{N}$ yield and yield removed $N(Y R N)$ in spring cereals and rapeseed $(n=60$ for two-row barley, $n=51$ for six-row barley, $n=65$ for oat, $n=44$ for wheat, $n=33$ for turnip rape, and $n=22$ for oilseed rape). Std, standard deviation of mean.

\begin{tabular}{lrrrrr}
\hline Crop & Mean & Std & $\begin{array}{c}\text { Std/ } \\
\text { mean }\end{array}$ & Min & Max \\
\hline $\mathrm{N}_{\text {yield }}\left(\mathrm{kg} \mathrm{ha}^{-1}\right)$ : & & & & & \\
Two-row barley & 81 & 4.2 & 5.2 & 70 & 89 \\
Six-row barley & 80 & 4.9 & 6.1 & 70 & 90 \\
Oat & 93 & 4.5 & 4.9 & 74 & 103 \\
Wheat & 82 & 6.2 & 7.6 & 69 & 93 \\
Turnip rape & 59 & 3.2 & 5.4 & 52 & 66 \\
Oilseed rape & 69 & 9.7 & 14.0 & 52 & 85 \\
YRN (\%): & & & & & \\
Two-row barley & 94 & 4.8 & 5.1 & 83 & 104 \\
Six-row barley & 94 & 6.0 & 6.4 & 81 & 107 \\
Oat & 110 & 5.5 & 5.0 & 87 & 122 \\
Wheat & 82 & 6.4 & 7.8 & 69 & 93 \\
Turnip rape & 59 & 3.2 & 5.5 & 51 & 65 \\
Oilseed rape & 66 & 9.4 & 14.2 & 50 & 81 \\
\hline
\end{tabular}

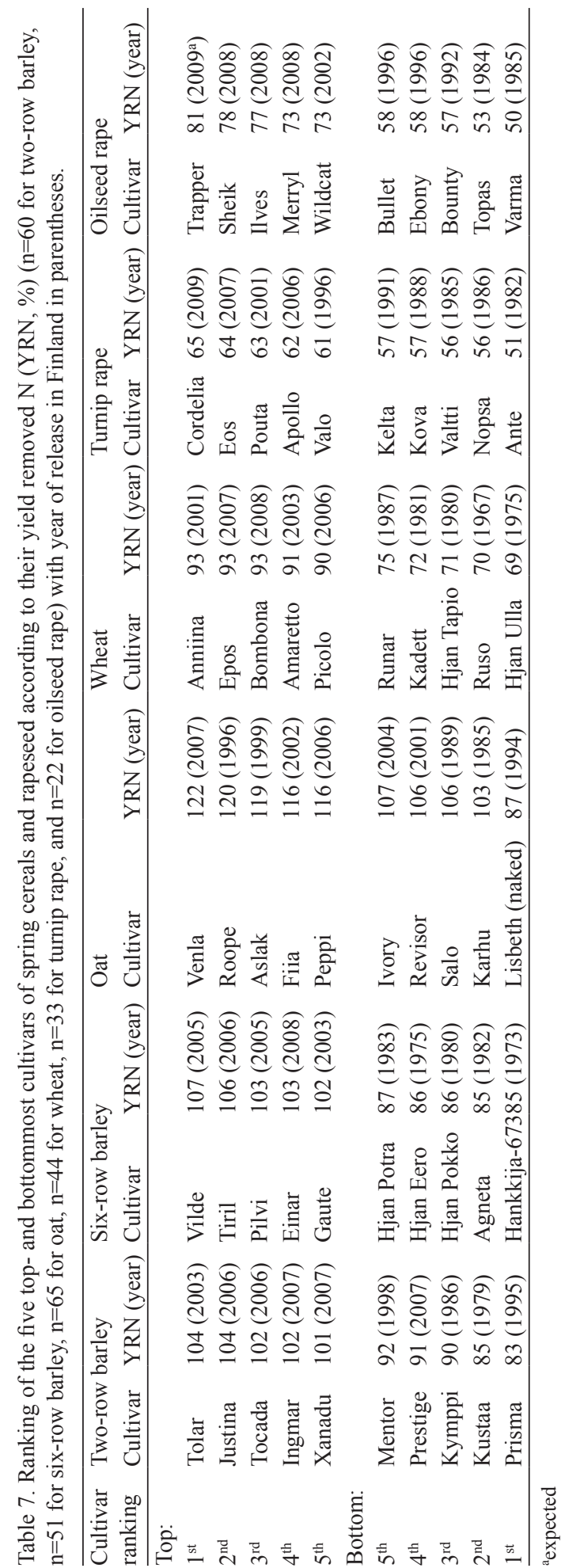


Peltonen-Sainio and Jauhiainen. Yield removed nitrogen of spring cereals and rapeseed

rape, and oilseed rape. In two-row barley the only exception to this tendency was for cultivar Prestige, which was only recently included on the National List of Plant Varieties by the Finnish Plant Variety Board. It has very low YRN. This was also true for oat cultivars Ivory and Revisor. Even though top cultivars of most crops were all released in the 2000s, oat differed by having two cultivars (Roope and Aslak) released during the late 1990s in the top YRN ranks, similarly to turnip rape cultivar Valo (Table 7). Substantial genetic gains in YRN were also evident for all crops when comparing the mean YRN among decades based on introduced cultivars (Table 8).

\section{Discussion}

Even though the environment had marked effects on YRN and $\mathrm{N}_{\text {yield }}$ of spring cereals, turnip rape, and oilseed rape, it was also evident that cultivar differences (Table 6) and genetic improvements in $\mathrm{N}$ traits were significant. For example, when comparing a large number of cultivars (ranging from 22 to 65 , depending on crop), according to their YRN the top five ranked cultivars were all released in Finland in the 2000s, the only exception being two late oat cultivars and a turnip rape cultivar, both released in the 1990s (Table 7). Moreover, only one two-row barley cultivar and two oat cultivars from the 2000s were among the five bottommost cultivars according to YRN comparisons. Results from additional analyses indicated that improvements were consistent and significant over time (Table 8), demonstrating the important role of plant breeding and cultivar selection in improving the balance between applied and harvested $\mathrm{N}$, thereby reducing the $\mathrm{N}$ leaching risk. Bertholdsson and Stoy (1995) and Foulkes et al. (1998) also reported that the most recent cultivars were adapted to higher fertilizer application $\mathrm{N}$ rates and they took up relatively more $\mathrm{N}$ from fertilizer compared with older cultivars.

Improved yields were associated with genetic improvements in YRN and $\mathrm{N}_{\text {yield }}$. On the other hand, $\mathrm{N}_{\text {grain }}$ was associated with YRN only in oat, even though the top ranked (according to YRN) wheat cultivar Anniina had only a moderate yield (4580 kg ha-1 compared with 5090-5610 kg ha-1 for the other top five cultivars), but exceptionally high $\mathrm{N}_{\text {grain }}(2.42 \%$ compared with $1.89-2.09 \%$ for other top five cultivars). Furthermore, crops with higher mean yields had higher YRN (Table 1). Consistent genetic gains in yield potential of all these crops have taken place during recent years in the northernmost European growing areas as recently reported: by ca. $26-41 \mathrm{~kg} \mathrm{ha}^{-1} \mathrm{y}^{-1}$ depending on spring cereal and ca. $17 \mathrm{~kg} \mathrm{ha}^{-1} \mathrm{y}^{-1}$ for turnip rape (Peltonen-Sainio et al. 2007 and 2009b). Harvest index has increased substantially through plant breeding, contributing to genetic yield gains, whereas total above-ground biomass has remained virtually unchanged (Austin et al. 1980, Bulman et al. 1993). The impact of yield increase on increase in YRN and $\mathrm{N}_{\text {yield }}$ was highest for turnip rape and oilseed rape and lowest for wheat, in the case of YRN, although for $\mathrm{N}_{\text {yield }}$ differences among cereals

Table 8. Mean of yield removed N (YRN, \%) for spring cereal and rapeseed cultivars ( $\mathrm{n}$ indicating their number) introduced into the experiments during different decades.

\begin{tabular}{lcccccccccccc}
\hline Decade & \multicolumn{2}{c}{ Two-row barley } & \multicolumn{2}{c}{ Six-row barley } & \multicolumn{2}{c}{ Oat } & \multicolumn{2}{c}{ Wheat } & \multicolumn{2}{c}{ Turnip rape } & \multicolumn{2}{c}{ Oilseed rape } \\
\cline { 2 - 13 } & $\mathrm{n}$ & YRN & $\mathrm{n}$ & YRN & $\mathrm{n}$ & YRN & $\mathrm{n}$ & YRN & $\mathrm{n}$ & YRN & $\mathrm{n}$ & YRN \\
\hline 1970 & 2 & 85 & 8 & 89 & 3 & 111 & 6 & 72 & 2 & 54 & 1 & 53 \\
1980 & 7 & 91 & 18 & 91 & 18 & 106 & 15 & 81 & 17 & 57 & 3 & 56 \\
1990 & 29 & 93 & 10 & 96 & 33 & 111 & 16 & 84 & 8 & 60 & 10 & 62 \\
2000 & 23 & 97 & 16 & 99 & 11 & 114 & 7 & 89 & 6 & 62 & 8 & 75 \\
$p$-value & & $<0.01$ & & $<0.001$ & & $<0.001$ & & $<0.001$ & & $<0.001$ & $<0.001$ \\
\hline
\end{tabular}


Vol. 19(2010): 341-353.

were not significant (Table 2). There was, however, a significant and negative association between yield and grain or seed $\mathrm{N}$ content for all crops: i.e. under highly productive conditions crops yielded relatively more per unit available, grain-allocated N.

It is possible that differences in $\mathrm{N}$ fertilizer rate of up to $15 \mathrm{~kg} \mathrm{~N} \mathrm{ha}^{-1}$, depending on crop, interfere with crop species comparisons. However, differences in $\mathrm{N}$ use for different field crops are very typical of farming in Finland. Furthermore, in these experiments, as is common farming practice, $\mathrm{N}$ was applied only at sowing and was expected to sustain growth for the entire period from sowing to maturity (Peltonen-Sainio et al. 2009d). Therefore, our results may represent the prevalent conditions in Finnish fields, except that yields are systematically higher for all crops grown in experiments than when grown on-farm (Peltonen-Sainio et al. 2009b). On the other hand, considering direct comparisons among YRN values is justifiable only in the cases of oat, two-row, and six-row barley, which all received $\mathrm{N}$ at $88-89 \mathrm{~kg} \mathrm{ha}^{-1}$ and for wheat and turnip rape receiving $101-102 \mathrm{~kg} \mathrm{~N}$ $\mathrm{ha}^{-1}$. It was evident that oat was superior regarding YRN averaging $110 \%$ and exceeding the values for two- and six-row barleys by 15 and 13 percentage units, respectively. Furthermore, the later maturing wheat and turnip rape differed even more. YRN for wheat was 25 percent units higher than that for turnip rape. Because we were only able to compare quantities of applied and harvested $\mathrm{N}$ in the long-term datasets, and had no information on $\mathrm{N}$ mobilized from soil nor on $\mathrm{N}$ content of vegetative biomass, we estimated the likely range ( $\mathrm{min}$ to max for all experiments and cultivars) for NUE and NHI. Although being only estimates, NUE and NHI ranges were far lower for turnip rape than for wheat or other spring cereals. These comparisons and findings highlight the advantageous role of oat over barley in crop rotations when early maturity is required, and that of wheat over turnip rape when later maturity is possible (in southern regions), solely considering better capacity to transfer applied $\mathrm{N}$ to harvested yield and reduce risk of $\mathrm{N}$ leaching. Also Granlund et al. (2000) emphasized with modelling the high risks of nitrate leaching in turnip rape under Finnish conditions. Turnip rape has, however, many prominent advantages as a break-crop (Smith et al. 2004; Shahbaz et al., 2006; Kirkegaard et al., 2008) especially in cereal rotations as a sole non-cereal break-crop.

Even though marked differences among crop species and cultivars were recorded, it was obvious that because YRN and $\mathrm{N}_{\text {yield }}$ were highly variable traits (Fig. 1 and 2), similarly as for grain yield, (Peltonen-Sainio et al. 2009a), genetic improvements were largely masked by variation attributable to growing conditions and because of the large numbers of cultivars included in the annual trials. In fact, for most crops $\mathrm{N}_{\text {yield }}$ and YRN were higher at early than latter part of the study period when averaged over years. Because year x crop and location $\mathrm{x}$ crop interactions were not significant sources of variation for yield, $\mathrm{N}_{\text {grain }}, \mathrm{N}_{\text {yield }}$, and YRN, compared with year, location, and their interaction (Table 3), differences among crop species often remained consistent despite large recorded differences attributable to conditions. Within year variability in YRN and $\mathrm{N}_{\text {yield }}$ ranged from modest in 2001 and 2004 for two- and six-row barley to substantial in 1989, 1990, and 2006 (Fig. 1 and 2). When considering the risks of an exceptionally low YRN, associated with higher risks of N leaching, we noticed that even though such years were evident, they were rare for cereals, although systematically low YRN was evident for turnip rape and oilseed rape. On the other hand, exceptionally high YRN (even over 150\%) were generally more frequent for cereals than exceptionally low values, indicating that soil-remobilized $\mathrm{N}$ was particularly significant in some experiments and resulted in excess uptake and $\mathrm{N}$ allocation to grains.

Water availability is a principal factor affecting $\mathrm{N}$ uptake and utilization by a crop and our study confirmed that $\mathrm{N}_{\text {yield }}$ depends on precipitation, and occasionally YRN also (Table 4). Average early and/or late season precipitation often benefited $\mathrm{N}_{\text {yield }}$ in cereals. Under dry conditions $\mathrm{N}$ uptake is disrupted, while in rainy seasons $\mathrm{N}$ leaching increases (Rankinen et al. 2007). There is thus considerable variability in $\mathrm{N}$ losses attributable to changes in weather conditions (Granlund et al. 2007). However, in this study elevated tempera- 
Peltonen-Sainio and Jauhiainen. Yield removed nitrogen of spring cereals and rapeseed

tures during early and/or late growth phases had a consistent negative impact on YRN and/or $\mathrm{N}_{\text {yield }}$ for all crops except oilseed rape (Table 5). Elevated temperatures, often coinciding with drought, are critical for yield determination (Ugarte et al. 2007), as also demonstrated for the northernmost European growing areas, where they result in yield penalties of up to $160 \mathrm{~kg} \mathrm{ha}^{-1}$ for spring cereals and $140 \mathrm{~kg} \mathrm{ha}^{-1}$ for oil crops for each degree rise in temperature (Peltonen-Sainio et al. 2010). Therefore, yield penalties caused by elevated temperatures are likely to increase the challenge of climate change regarding $\mathrm{N}$ leaching, in addition to the projected increases in annual precipitation, milder winters, higher soil temperatures, and increased $\mathrm{N}$ mobilization from soil at northern latitudes (PeltonenSainio et al. 2009d).

In conclusion, we found that inter-annual and within year variation in YRN is marked. YRN can, however, be improved through cultivar selection and designing better crop rotations because modern cultivars were generally superior to their predecessors. However, elevated temperatures that cause yield penalties for cereals and Brassica crops under long-day conditions due to hastened development, often resulted in reduced YRN.

Acknowledgements. The authors are grateful to the numerous partners who participated in organizing the MTT Official Cultivar Trials. The work was financed by the Finnish Ministry of Agriculture and Forestry and MTT Agrifood Research Finland as a part of an on-going consortium project entitled Followup of the effectiveness of the Agri-Environmental Programme in Finland (MYTVAS 3).

\section{References}

Austin, R.B., Bingham, J., Blackwell, R.D., Evans, L.T., Ford, M.A., Morgan, C.L. \& Taylor, M. 1980. Genetic improvements in winter wheat yields since 1900 and associated physiological changes. Journal of Agricultural Science 94: 675-689.

Bertholdsson, N.O. \& Stoy, V. 1995. Accumulation of biomass and nitrogen during plant growth in highly diverg- ing genotypes of winter wheat. Journal of Agronomy and Crop Science 175: 167-182.

Bulman, P., Mather, D.E. \& Smith, D.L. 1993. Genetic improvement of spring barley cultivars grown in eastern Canada from 1910 to 1988. Euphytica 71: 35-48.

Bulman, P. \& Smith, D.L. 1994. Post-harvest uptake, retranslocation, and partitioning in spring barley. Crop Science 34: 977-984.

Calderini, D.F., Torres-León, S. \& Slafer, G.A. 1995. Consequences of wheat breeding on nitrogen and phosphorus yield, grain nitrogen and phosphorus concentration and associated traits. Annals of Botany 76: 315-322.

Cox, M.C., Qualset, C.O. \& Rains, D.W. 1985. Genetic variation for nitrogen assimilation and translocation in wheat: II. Nitrogen assimilation in relation to grain yield and protein. Crop Science 25: 435-440.

Feil, B. 1997. The inverse yield-protein relationship in cereals: possibilities and limitation for genetically improving the grain protein yield. Trends in Agronomy 1: 103-119.

Foulkes, M.J., Sylvester-Bradley, R. \& Scott, R. 1998. Evidence for differences between winter wheat cultivars in acquisition of soil mineral nitrogen and uptake and utilization of applied fertilizer nitrogen. Journal of Agricultural Science 130: 29-44.

Gauer, L.E., Grant, C.A., Gehl, D.T. \& Bailey, L.D. 1992. Effects of nitrogen fertilization on grain protein content, nitrogen uptake and nitrogen use efficiency of six spring wheat (Triticum aestivum L.) cultivars in relation to estimated moisture supply. Canadian Journal of Plant Science 72: 235-241.

Granlund, K., Bärlund, I., Salo, T., Esala, M. \& Posch, M. 2007. The effect of decreasing fertilization on agricultural nitrogen leaching: a model study. Agricultural and Food Science 16: 376-386.

Granlund, K., Rekolainen, S., Grönroos, S.J., Nikander, A. \& Laine, Y. 2000. Estimation of the impact of fertilisation rate on nitrate leaching in Finland using a mathematical simulation model. Agriculture, Ecosystem \& Environment 80: 1-13.

Hakala, K., Kontturi, M. \& Pahkala, K. 2009. Field biomass as global energy source. Agricultural and Food Science 18: 347-365.

Hocking, P.J., Randall, P.J. \& DeMarco, D. 1997. The response of dryland canola to nitrogen fertilizer: partitioning and mobilization of dry matter and nitrogen, and nitrogen effects on yield components. Field Crops $R e-$ search 54: 201-220.

Kangas, A., Laine, A., Niskanen, M., Salo, Y., Vuorinen, M., Jauhiainen, L. \& Nikander, H. 2005. Results of official variety trials 1997-2005. MTT:n selvityksiä 83 . Kasvintuotanto. 192 p. ISBN 951-729-934-6. (Partly in English).

Kelly, J.T., Bacon, R.K. \& Wells, B.R. 1995. Genetic variability in nitrogen utilization at four growth stages in soft red winter wheat. Journal of Plant Nutrition 18: 969-982.

Kirkegaard, J., Christen, O., Krupinsky, J. \& Layzell, D. 2008. Break crop benefits in temperate wheat production. Field Crops Research 107: 185-195.

Le Gouis, J., Béghin, D., Heumez, E. \& Pluchard, P. 2000. Genetic differences for nitrogen uptake and nitrogen utilisation efficiency in winter wheat. European Journal of Agronomy 12: 163-173. 
Vol. 19(2010): 341-353.

Liao, M.T., Fillery, I.R.P. \& Palta, J.A. 2004. Early vigorous growth is a major factor influencing nitrogen uptake in wheat. Functional Plant Biology 31: 121-129.

Liao, M.T., Palta, J.A. \& Fillery, I.R.P. 2006. Root characteristics of vigorous wheat improve early nitrogen uptake. Australian Journal of Agricultural Research 57: 1097-1107.

Muurinen, S. 2007. Nitrogen dynamics and nitrogen use efficiency of spring cereals under Finnish growing conditions. Ph.D. thesis, University of Helsinki, Department of Applied Biology, Section of Crop Husbandry, Publication no. 29. http://www.doria.fi/handle/10024/4221

Muurinen, S., Kleemola, J. \& Peltonen-Sainio, P. 2007. Accumulation and translocation of $\mathrm{N}$ in spring cereal cultivars differing in NUE. Agronomy Journal 99: 441-449.

Noulas, C., Stamp, P., Soldati, A. \& Liedgens, M. 2004. Nitrogen use efficiency of spring wheat genotypes under field and lysimeter conditions. Journal of Agronomy and Crop Science 190: 111-118.

Pahkala, K., Hakala, K., Kontturi, M. \& Niemeläinen, O. 2009. Peltobiomassat globaalina energianlähteenä. Maa- ja elintarviketalous 137.53 p. ISBN 978-952487-214-0 (In Finnish)

Papakosta, D.K. 1994. Analysis of wheat cultivar in grain yield, grain nitrogen yield and nitrogen utilization efficiency. Journal of Agronomy and Crop Science 172: 305-316.

Papakosta, D.K. \& Gagianas, A.A. 1991. Nitrogen and dry matter accumulation, remobilization and losses for Mediterranean wheat during grain filling. Agronomy Journal 83: 864-870.

Peltonen-Sainio, P., Jauhiainen, L. \& Hakala, K. 2009a. Are there climate change induced increases in variability of major field crops in the northernmost European conditions? Agricultural and Food Science 18: 206-226.

Peltonen-Sainio, P., Jauhiainen, L. \& Hakala, K. 2010. Crop responses to temperature and precipitation according to long-term multi-location trials at high latitude conditions. Journal of Agricultural Science, in press. Special issue on Climate Change and Agriculture. doi:10.1017/ S0021859610000791

Peltonen-Sainio, P., Jauhiainen, L. \& Hannukkala, A. 2007. Declining rapeseed yields in Finland: how, why and what next? Journal of Agricultural Science 145: 587-598.

Peltonen-Sainio, P., Jauhiainen, L. \& Laurila, I.P. $2009 \mathrm{~b}$. Cereal yield trends in northern European conditions: Changes in yield potential and its realisation. Field Crops Research 110: 85-90.

Peltonen-Sainio, P., Jauhiainen, L., Rajala, A. \& Muurinen, S. 2009c. Tiller traits of spring cereals in tiller-depressing long day conditions. Field Crops Research 113: 82-89.

Peltonen-Sainio, P., Muurinen, S., Rajala, A. \& Jauhiainen, L. 2008. Variation in harvest index of modern spring barley, oat and wheat under northern conditions. Journal of Agricultural Science 146: 35-47.

Peltonen-Sainio, P., Rajala, A., Känkänen, H. \& Hakala, K. 2009d. Improving farming systems in northern European conditions. Pp: 71-97. In: V.O. Sadras. and D. Calderini (ed.) Crop Physiology: Applications for Genet- ic Improvement and Agronomy. Elsevier, Amsterdam, The Netherlands.

Rajala, A., Peltonen-Sainio, P., Kauppila, R., Wilhelmson, A., Reinikainen, P. \& Kleemola, J. 2007. Within-field variation in grain yield, yield components and quality traits of two-row barley. Journal of Agricultural Science 145: 445-454.

Rankinen, K., Granlund, K. \& Rita, H. 2007. Simulated nitrogen leaching, nitrogen mass field balances and their correlation on four farms in south-western Finland during the period 2000-2005. Agricultural and Food Science 16: 387-406.

SAS Institute Inc., 1999. SAS/STAT User's Guide, Version 8, Cary, NC: SAS Institute Inc. 3809 p.

Shahbaz, A.M., Oki, Y., Adachi, T., Murata \& Y. \& Khan, M.H.R. 2006. Phosphorus starvation induced root-mediated $\mathrm{pH}$ changes in solublization and acquisition of sparingly soluble $\mathrm{P}$ sources and organic acids exudation by Brassica cultivars. Soil Science and Plant Nutrition 52: 623-633.

Sinebo, W., Gretzmacher, R. \& Edelbauer, A. 2003. Genotypic variation for nitrogen use efficiency in Ethiopian barley. Field Crops Research 85: 43-60.

Singh, V.P. \& Arora, A. 2001. Intraspecific variation in nitrogen uptake and nitrogen utilization efficiency in wheat (Triticum aestivum L.). Journal of Agronomy and Crop Science 186: 239-244.

Slafer, G.A., Andrade, F.H. \& Feingold, S.E. 1990. Genetic improvement of bread wheat (Triticum aestivum L.) in Argentina: Relationships between nitrogen and dry matter. Euphytica 50: 63-71.

Smith, B.J., Kirkegaard, J.A. \& Howe, G.N. 2004. Impacts of Brassica break-crops on soil biology and yield of following wheat crops. Australian Journal of Agricultural Research 55: 1-11.

Spiertz, J.H.J. \& de Vos, N.M. 1983. Agronomy and physiological aspects of the role of nitrogen in yield formation of cereals. Plant and Soil 75: 379-391.

Syväsalo, E., Regina, K., Turtola, E., Lemola, R. \& Esala, M. 2006. Fluxes of nitrous oxide and methane, and nitrogen leaching from organically and conventionally cultivated sandy soil in western Finland. Agriculture, Ecosystem \& Environment 113: 342-348.

Ugarte, C., Calderini, D.F. \& Slafer, G.A. 2007. Grain weight and grain number responsiveness to pre-anthesis temperature in wheat, barley and triticale. Field Crops $R e$ search 100: 240-248.

Welch, R.W. \& Leggett, J.M. 1997. Nitrogen content, oil content and oil composition of oat cultivars (A. sativa) and wild Avena species in relation to nitrogen fertility, yield and partitioning of assimilates. Journal of Cereal Science 26: 105-120.

Woodend, J.J., Glass, A.D.M. \& Person, C.O. 1986. Intraspecific variation for nitrate uptake and nitrogen utilization in wheat ( $T$. aestivum L.) grown under nitrogen stress. Journal of Plant Nutrition 9: 1213-1225.

Wych, R.D. \& Stuthman, D.D. 1983. Genetic improvement in Minnesota-adapted oat cultivars released since 1923. Crop Science 23: 879-881. 